\title{
Olga Levytska
}

$\mathrm{PhD}$ in Economics,

Senior Researcher of Department

of Social and Humanitarian

Development of the Region,

State Institution 'Institute of Regional Research

named after M.I. Dolishniy of the NAS of Ukraine',

4 Kozelnytska Str., Lviv, 79026, Ukraine,

o.levytska@gmail.com

\section{Olga Mulska}

$\mathrm{PhD}$ in Economics,

Junior Researcher of Department

of Social and Humanitarian

Development of the Region,

State Institution 'Institute of Regional Research

named after M. I. Dolishniy of the NAS of Ukraine',

4 Kozelnytska Str., Lviv, 79026, Ukraine,

oliochka.mulska@gmail.com

\section{EMERGING TRENDS IN THE LABOUR MARKET OF UKRAINE IN TERMS OF GLOBAL TRANSFORMATIONS}

Abstract: Labour markets are affected by continuous structural and functional transformations concerning all the participants of labour relations. As a result, new types of relations have been formed as well as new attitudes to work environment, flexibility and mobility opportunities have occurred. In the current article, the authors identify and systemize the main Ukrainian labour market trends under conditions of global digitalization, human resource migration and transformation of work concepts and practices. Considerable attention is paid to a comparative analysis of standard (traditional) and non-standard forms of employment, to discussion of significant disadvantages and possible risks in non-standard work, and to identification of a precarious class of workers. The authors also analyse peculiarities of the development of non-standard forms of employment by the example of the information and communications technology sector of Ukraine. This sector is considered to be the biggest driver for innovations in the national labour market and the most favourable, fast developing platform for implementation of new work practices. 
To manage the risks and challenges of emerging trends in the labour market of Ukraine, the main priorities of a proactive employment policy based on new work concepts are defined and substantiated.

Keywords: labour market, work concept, non-standard employment, precarious workers, information and communications technology sector, employment policy.

JEL classification: J01，J21, J5

\section{Introduction}

Over the years of independence, Ukraine has passed through many socio-economic transformations and reforms, which led to fast integration into the world economy. Integration processes have also affected the national labour market setting new opportunities and challenges. Today, Ukraine is one of the biggest donor countries providing higher developed economies with the workforce. At the same time, Ukraine is short in qualified workers, especially in the health care system and education sector, also crucially short in vocational workers and technicians. Such labour market imbalances are being deepened by global development of information and communication technologies (ICT), which has resulted in the information revolution accompanying the fourth industrial revolution (4IR), and by intensification of disparities in economic growth by countries. Due to these processes, external labour migration in Ukraine has reached the very high point, significantly affecting the behaviour of all participants in the national labour market, modifying rules and principles of their interaction, setting new regulations of employment and related issues.

Theoretical and practical aspects of global and national labour markets' development are widely studied by scientists and practitioners. Thus, many western scholars analyse modern trends and transformations in social and labour relations (Bang, G., Joyce, W., Nohria, N., Robertson, B., Schmid, G.), improvement of employment policies at different levels of regulation (Sven, J., Kawar, M., Kring, S., Dhéret, C., Roden, J., Charlesworth, S.), the impact of ICT on human resource management (Schönberg, U., Webster, F., Ludsteck, J., Tapscott, D., Krzywicki, J., etc.). Peculiarities of development of the Ukrainian labour market and 
labour relations are in focus of research of Libanova, E., Hrishnova, O., Semykina, M., Bohynya, D., Malynowska, O., Kolot, A., Poznyak, O., Sadova, U., Semiv, L., Bil, M. and many other scientists. These issues are actively discussed in scientific community and among the general public, but the influence of global social and economic transformations on the labour market of Ukraine is insufficiently studied.

The aim of the research is to systematize the emerging trends in the national labour market, consider new work concepts, risks and opportunities connected with occurrence of non-standard forms of employment, and analyse the growing labour market in ICT sector of Ukraine.

\section{Research results}

\section{Main trends and prospects for development of the Ukrainian la- bour market}

At the present time, the labour concepts and theories are being checked for new and original means in solving the problems of employment, social protection and inclusion of employees. The existential principles of modern concepts of labour were developed by the German economist Gunter Schmid in the '90s and later on. He introduced the concept of the transitional labour market as a new European (in particular, German) employment strategy that supported institutional arrangements to cope with structural changes, driven by social risks, and with a theoretical experiment in the European Union (Schmid 1995, p. 429). The key point of the concept is that the new forms of social security are supposed to cover risks of involuntary unemployment (by establishing institutionalised 'bridges' at critical junctures in individuals' working lives) as well as make the labour market more flexible and promising for groups at high risk of social exclusion (Schmid 2006, p. 2-3). Since its commencement, the transitional labour market concept has undergone various changes and further elaborations (by Auer, P., Crimmann, A., Gazier, B., Gustafsson, S., De Koning, J., Wilthagen T., etc.). Now it is known as a 'flexicurity' concept - the combination of the labour market flexibility and security for workers. Many countries have already implemented the principles of 'flexicurity', e.g. wage insurance in Germany and Switzerland, life-course saving plan in the Netherlands and Denmark, and mobil- 
ity insurance in Austria. The aim of such initiatives is to provide more flexibility at a reasonable level of security both for the employers and employees. As for Ukraine, 'flexicurity' principles are on the way to theoretical comprehension and search for possibilities of their realization for managing the risks of unemployment, partial employment and insufficient social benefits for workers, as well as for reducing the occupational segregation and segmentation of the national labour market. Adaptability of the 'flexicurity' concept in Ukraine's contexts requires consideration of new priorities of the European employment policy, namely the formation of an effective employment strategy at the state, regional and local levels, setting up of social security mechanisms for economically inactive people; elaboration of comprehensive strategies of lifelong learning; development of proactive policies and regulations.

Thus, the growing popularity of the 'flexicurity' concept has initiated new trends in global labour markets - flexibilization along with securitization of employment relationships (the so-called 'flexicurization'). These processes are associated with occurrence of various flexible forms of employment, often titled as 'non-standard', 'non-traditional', 'atypical', 'temporary' or 'precarious' one. Although each term emphasizes some of its features, all they are closely related and refer to employment relationships that do not conform to the standard of full-time, regular, open-ended employment with a single employer over a long time span (Eurofound 2017 , Available from: https://www.eurofound.europa.eu/observatories/eurwork/industrialrelations-dictionary/atypical-work). Non-standard forms of employment are the result of changing work concepts and practices, as well as the consequence of setting up the new types of entrepreneurship all over the world, which are being undertaken in real-time mode via the Internet to provide services, processes and corporate management at a distance. Therefore, due to overwhelming digitization and workplace virtualization, the workflow is less determined by time, place and manner and more oriented towards effects monitoring (including through new tools of work monitoring and evaluation).

Among numerous forms of flexible employment, we differentiate: a) full employment in terms of flexible working time; b) part-time em- 
ployment (work with fewer working hours per week); c) temporary employment (work with limited arrangement); d) secondary employment (additional employment outside the main work); e) occupation under civil law contracts; f) home work; g) work on demand (including freelance); h) remote employment (virtual jobs); i) temporary employment (staff leasing, outstaffing and staff outsourcing); j) self-employment; k) informal employment (including unpaid family and care work, forms of informal self-employment); 1) unregistered employment in the formal sector. At the same time, the International Labour Organization (ILO) comprises four different types of waged employment that deviate from the standard employment relationship. These include temporary employment (casual work and fixed-term contracts); part-time work and on-call work arrangements; triangular employment relationships (temporary agency work and other forms of labour brokering or labour dispatch); and disguised employment or dependent self-employment relationships (where workers are legally classified as self-employed but someone else directs their work) (International labour organization, 2018, Available from: http://www.ilo.org/global/topics/non-standard-employment/lang-en/ index.htm). It should be noted that the above mentioned classifications are relative since many of the flexible forms of employment are combined (for example, self-employment can be at the same time informal, remote, with a flexible working time and on-demand). Currently, Ukraine is facing the same economic transformations as the developed countries are. Having initiated many technological and organizational innovations, these countries apply new approaches to the labour market formation and regulation taking into account non-standard employment, unconventional work arrangements and other trends. Many of these trends start to emerge in Ukrainian labour market, especially in ICT, service sector, creative industries (Fig. 1) 


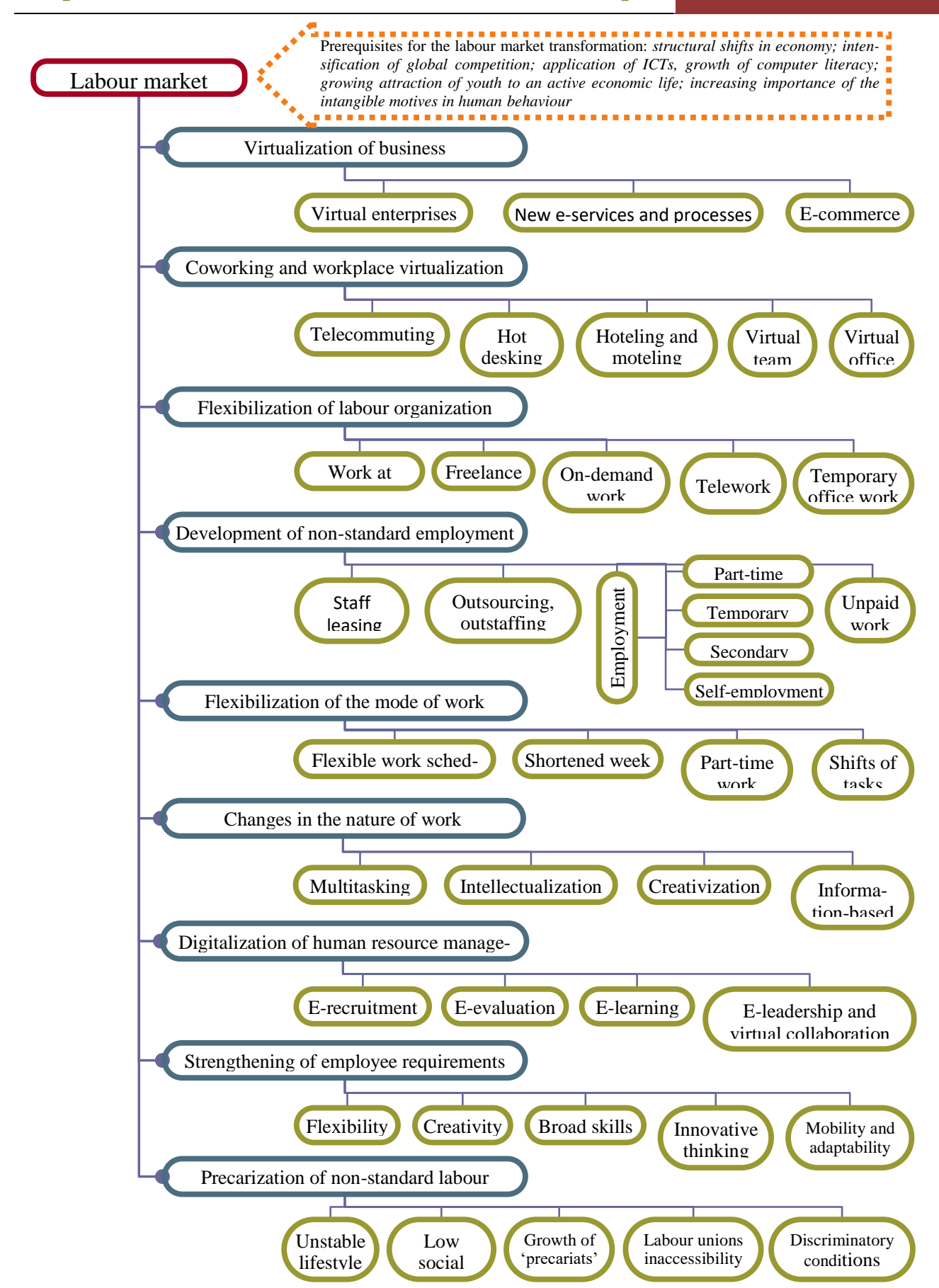

Figure 1: Modern trends in the labour market of Ukraine

Source: compiled by the authors on the basis of (Bil 2016, p. 130; Ivanova 2013, p. 109;

Shylnikova 2013, p. 193; Startupdepot, 2017, Available from:

http://startupdepot.lviv.ua/yak-zminyvsya-frilans-v-ukrayini-za-5-rokiv; Tsizhma 2013,

p. 198) 
Most of the labour market transformations are determined by such global prerequisites as, for instance, development of the information revolution (total digitalization of human activity and market relations, consumerization of ICT, growing computer literacy among population, occurrence of 'information' ('knowledge') workers, who use information to assist in making decisions and taking actions, or create information that informs the decisions or actions of others), structural shifts in economy related to prevalence of the service sector, intensification of global competition in various markets and spheres of economy, as well as by increasing importance of the intangible (immaterial) motives in human behaviour. Application of ICTs, to a great extent, initiated development of virtual employment all over the world. Virtualization allowed for modification of spatial parameters of work and active use of flexible working modes. In this regard, the main features of the modern labour concept lie in intellectualization of work, in ICT-determined employment, in high skills of the workforce, associated with the formation of a new information and professional space, in increased employment flexibility, in informal virtual arrangements and in the growth of self-employment.

Nowadays more and more people tend to choose new forms of employment and working arrangements (fixed-term contracts, switches from full-time (namely, 40 hours per week in Ukraine) to part-time work, shifts of tasks, self-employment and other forms of flexibility realization). Consequently, this causes increase in precarious employment and permanent re-skilling. According to ILO reports, a part-time work is becoming more widespread in the global labour markets, especially in those segments offered to immigrants. Thus, in 2017 the share of part-time workers by separate countries was the following: in Estonia - 21.2\%, in Japan $24.0 \%$, in Canada $-29.7 \%$, in the UK $-33.7 \%$, in Germany $-33.4 \%$, in Italy $-26.2 \%$ and in Ukraine $-9.6 \%$ (ILOSTAT, 2018, Available from: http://www.ilo.org/ilostat-files/Documents/Excel/MBI_524_EN.xlsx).

Although non-standard forms of employment gain popularity, a significant part of them is still outside the legal framework (especially in case of Ukraine and other developing countries). By the official data, during 2017 the number of officially employed people in Ukraine decreased by 125.3 thous. pers. or by $0.9 \%$, and the number of those who independ- 
ently organized their activity (self-employed) increased by 6.9 thous. pers. or by $0,3 \%$. In the first half of 2017 the number of informally employed population decreased by 299.1 thous. pers. in comparison with the corresponding period of the previous year and made up $3.7 \mathrm{mln}$ people (that was $22.7 \%$ of the total number of employed population). It is of note that informal employment is usually inherent in individual socioeconomic groups. Thus, by employment status criterion, informal labour relations, as seen from Fig. 2, predominated in the sector of selfemployment, where the share of the unofficially working population in 2017 was 74.3\%. However, among those who were in a status of employed workers - informal employment covered only $25.7 \%$. Other structural changes in the Ukrainian labour market concerned an increase in proportion of employees among the officially working population (from $86.9 \%$ to $84.9 \%$ in $2016-2017$ ). At the same time, reverse processes occurred among the informally employed population (decrease from $15.1 \%$ to $13.1 \%$ accordingly) (Fig. 2). The analysis presented reveals the processes of movement to the shadow economy due to the growing informal segment of the national labour market.

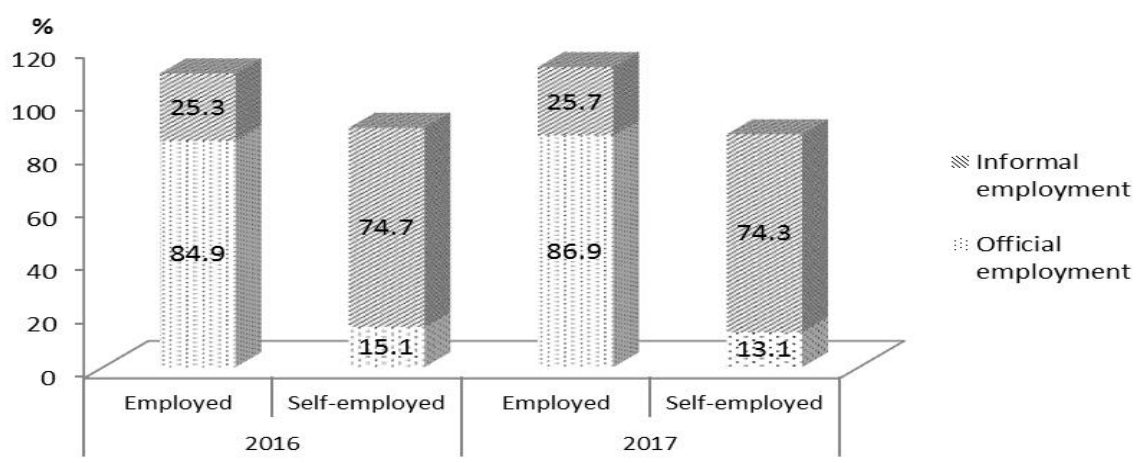

Figure 2: Formal and informal employment by status in Ukraine

(\% of the corresponding employment status and form)

Source: elaborated by the authors according to (State Statistics Service of Ukraine, 2017 (b), p. 4-5)

Self-employment itself has got various subsets, one of which is freelancing. Many people associate freelancing with self-employment but these terms differ. Self-employment is a tax status requiring submission of accounts, expenses slips, etc. Running a business in this status, a per- 
son may employ him/herself and other workers for the purpose of providing services/products for different clients. Meanwhile, freelancing refers to temporary working for a firm or a person (labour broker, agency or labour dispatch) for pay without using an office in a company full-time. Freelancers do not get sick pay and other social benefits what makes them a 'precarious workers'.

Over the past five years, the main indicators of the freelance labour market development in Ukraine have shown its rapid growth. However, 2016 was a critical year for the freelancing in Ukraine. A positive impetus was the adoption and signing of Law No. 4496, which has abolished administrative barriers to export of services and greatly simplified the legal procedure for doing business by freelancers. This simplification legalized freelance as an activity, and now Ukraine has all chances to enter the 3rd place in the world freelance area (at this stage, Ukraine ranks 4th position after India, the USA and the Philippines). Looking backwards, it should be emphasised that Ukraine's freelance market has been dynamically developing since 2006. In the period from 2006 to 2011, Ukrainian freelancers earned 38 mln dollars.

Over the next five years, the market has rapidly risen: the official number of freelancers grew by $27.4 \%$ and their earnings increased by $49.0 \%$ (Fig. 3). In the period 2012-2017, total earnings of freelancers made up $262 \mathrm{mln}$ dollars. Thus, in general, it amounts to $300 \mathrm{mln}$ dollars over the past ten years. It is worth noting that Ukrainian freelancers started earning more because of the high quality of their services and skill enhancement, both technically and in terms of the ability to sell these skills. 


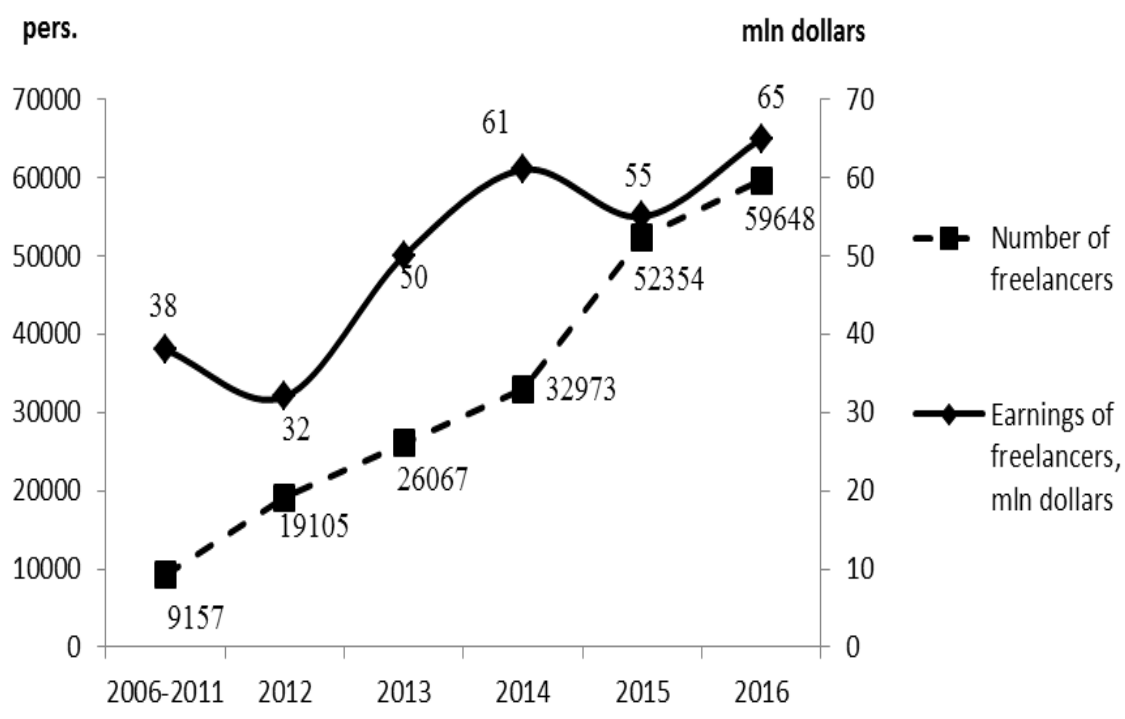

Figure 3: Dynamics of the freelance labour market in Ukraine

Source: elaborated by the authors according to (Startupdepot, 2017, Available from: http://startupdepot.lviv.ua/yak-zminyvsya-frilans-v-ukrayini-za-5-rokiv/)

\section{ICT-caused transformations in the labour market of Ukraine}

As previously mentioned, the ICT sector is the most favourable platform for implementation of new forms of employment and work practices. It is a rapidly growing driver for innovations in the Ukrainian labour market, an attractive industry accumulating big investments and engaging many highly qualified workers. In the current economy, development of ICT to a large extent determines competitiveness of a country in the world markets. Therefore, analysis of peculiarities of the Ukrainian ICT industry growth and its impact on the labour market development is of a special interest.It should first of all be noted that the ICT sector in Ukraine takes the leading place among European countries in ICT outsourcing and software development. This industry greatly contributes to new employment opportunities and new job creation in various segments (in software development and distribution, in technology and equipment production and sale, in ICT service). The most leading-edge jobs concern cognitive computing engineering (machine learning specialist), blockchain engineering, Graphics Processing Unit cluster engineering, virtual reality engineering, Internet of things architecting, computer security in- 
cident responding and etc. These jobs specify novel skill requirements to employees, intensify competition in the global labour markets, as well as promote labour migration. Ukraine's ICT labour market has rapidly grown in a number of workers over the past decade. Although dynamics of the total number of people working in the sector shows a downward trend in the recent four years, the number of, specifically, information technology (IT) specialists, on the contrary, has risen (Fig. 4). In 2013 there were 299.9 thous. total workers engaged, while in 2016 their number declined to 275.2 thous. pers. At the same time, the stock of IT specialists in 2013-2016 has increased from 75.0 to 100.1 thous. pers. and is foreseen to keep on rising. Obviously, IT specialists make up the biggest share of the total ICT workers. Even though there is a 33.5\% growth of the very IT specialists in the period analysed, the market is still understaffed because of the unsatisfied demand for this type of professionals and rapidly changing skill requirements. In addition to the absolute value changes, distinct structural transformations have concerned the status of employment in the current market. In 2016 the number of employed workers decreased in $21.2 \%$ (from 210.6 to 165.9 thous. pers. in the period 2013-2016). The reason for this trend is the growth of the selfemployed persons and income increases from a business they carry on.

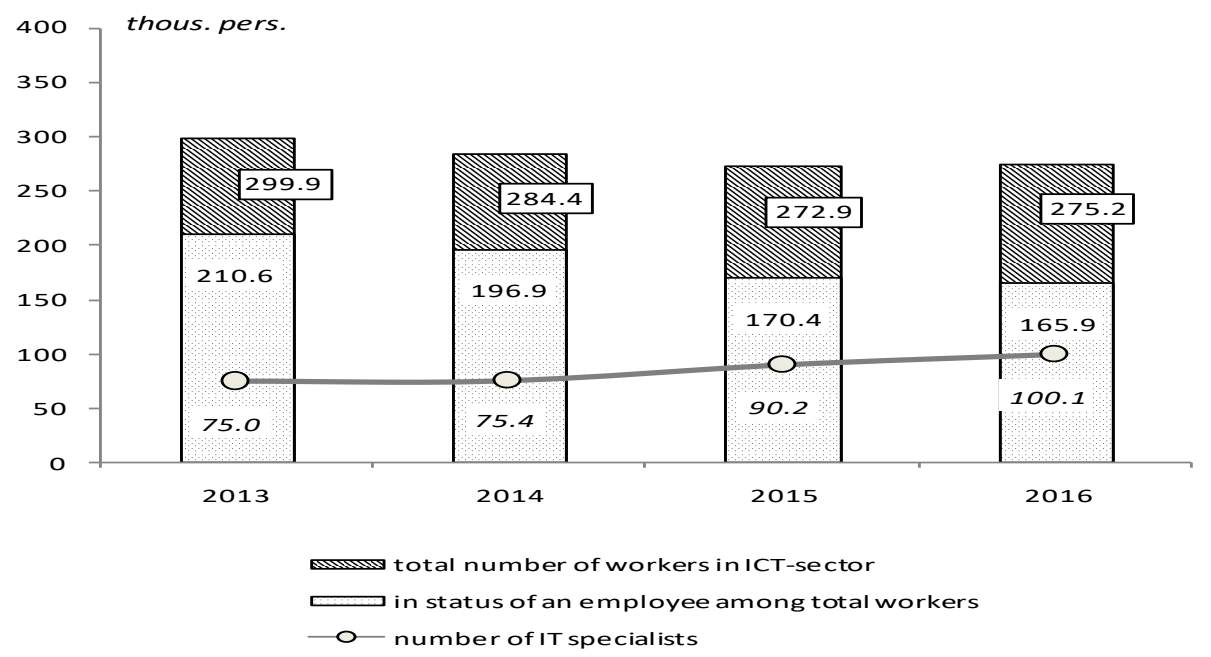

Figure 4: Dynamics of the ICT labour market in Ukraine in 2013-2016 
Source: elaborated by the authors on the basis of (State Statistics Service of Ukraine, 2017 (a), p. 172;DOU, 2016, Available from: https://dou.ua/lenta/articles/2016-summary)

Most of Ukrainian freelancers work in ICT industry, which is currently actively developing. This is one of the few spheres of the national economy representing a sustainable positive dynamics, while it is of particular importance at both the macro and micro levels. The ICT is a broad concept that includes the following categories: web development, design, social media marketing (SMM), copywriting, translation, architecture, etc. (Fig. 5).

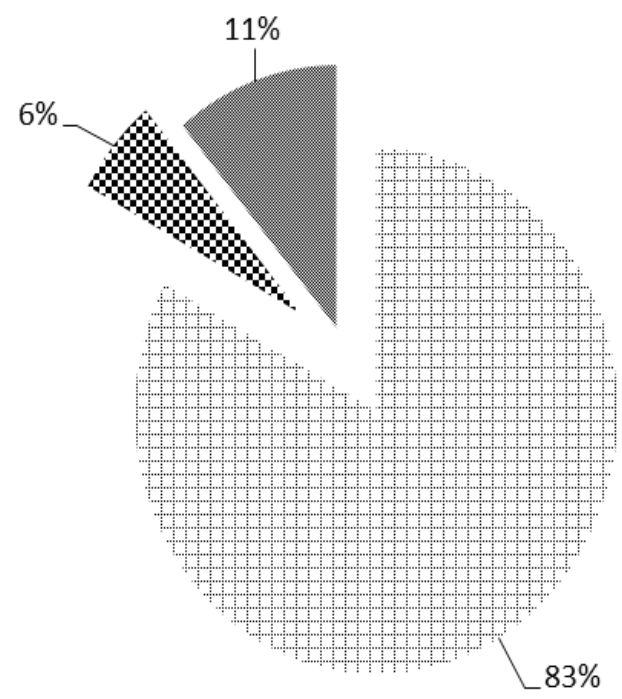

Information Technology (Web, Mobile and Software Development)

8 Design and creativity

: Other categories (translation, SMM, sales and marketing, engineering, architecture, etc.)

Figure 5: The market share of Ukraine's freelance by ICT categories, 2016

Source:Startupdepot, 2017, Available from: http://startupdepot.lviv.ua/yak-zminyvsya-frilans-v-ukrayini-za-5-rokiv

As seen from Fig. 5, during the last five years the sectoral composition of the freelance market has changed and come to $83 \%$ of freelancers working in web, mobile and software development, $11 \%$ - in translation, SMM, sales and marketing, engineering, etc., and 6\% - in design and creativity.

There is also another trend regarding the growing feminization of the 
national ICT industry. The share of women engaged in the mentioned sector goes from $8.1 \%$ in 2013 to $15.0 \%$ in 2016 (DOU, 2016, Available from: https://dou.ua/lenta/articles/2016-summary). It is known that women tend to be underpaid when comparing to men. Such inequality is especially crucial in case of traditional spheres and standard forms of employment. For instance, in the ICT industry and other advanced sectors of economy women are usually less discriminated. Generally, in 2016 the average monthly earnings in the Ukrainian ICT industry were equal to approximately 2,000 dollars per IT worker (while the average monthly earnings in Ukraine were only 175 dollars at that time). Although the amounts vary from 1,450 dollars for project managers to 3,150 dollars for senior front-end developers (DOU, 2016, Available from: https://dou.ua/lenta/articles/2016-summary), the national IT workers are still less paid in comparison with the specialists abroad. It resulted in an active development of ICT staff outsourcing and offshoring, thus making Ukraine one of the leading countries in supplying the required human resources.

On the one hand, there are many benefits of current trends in the national labour market, usually associated with a new creative jobs, flexible working mode and mobility, simplification of hiring processes, better wages, performance-based payments, skill upgrading, organizational and managerial innovations, but on the other, virtualization, digitalization and flexibalization of labour and human resource management are accompanied by various challenges, risks and deprivations. The most crucial among them can be defined as the following:

1. Part-time, temporary and other flexible arrangements deprive workers of many benefits they would obtain in case of secure, long-term employment, namely, social and job protection (sick pay, maternity and child care benefits, benefits for industrial injury or work-related illness, healthresort treatment), seniority bonuses, career growth and promotion etc.

2. Agency employees (freelancers and independent contractors) working under unsafe, hazardous conditions do not have the right to hazard pay, since they are officially on the staff of recruitment agency with no harmful working environment.

3. Precarious work and labour relationships (resulting from non- 
standard employment or crucial transformations in the labour market) lead to insecure existence, unstable lifestyle and work without social guarantees and reliable income. Consequently, the specific social class of 'precariats' is continuously growing all over the world due to representatives of the so-called 'creative professions' (actors, writers, artists, designers, IT-specialists, etc.) and labour migrants. This type of workers is deprived of the possibility of collective protection of their labour rights (through membership in trade unions).

4. Excess in information, as an integral part of modern labour practices, causes serious health problems related to prolonged stress and lifemanagement difficulty (for example, the burn-out syndrome).

5. Human resource mobility (spatial, virtual, social) contributes to formation of 'precarious workers', as well as often is accompanied by social exclusion, estrangement and discrimination (especially among migrants), reduced motivation, loyalty and commitment of employees (namely, the remote workers).

6. Growing share of informal (unregistered) labour relations provokes an increase in the 'shadow' economy and the state budget shortage.

Considering all the challenges and weak points of the current labour market transformations, it should be noted that there is a need for proactive, flexible and securitized employment policy. Ukraine, as a developing country with the on-going social and economic reforms, is in search of an efficient employment policy and better labour market regulation. Therefore, Ukraine should support implementation of ICTs in the labour market, promote new types of social and labour relationships, as well as new management approaches.

In this context, the main principles and priorities of employment policy of Ukraine, that must be set and implemented, refer to:

- ratification of ILO Conventions concerning new forms of employment and flexible working mode, improvement of the Labour Code of Ukraine according to the international labour standards and advanced practices;

- amendment of the Law of Ukraine 'On collective contracts and agreements' in respect of treaties and agreements concluded at different levels (the national, regional, sectoral and industrial); 
- creation of new jobs and workplaces in the ICT sector, creative industries and other fast growing spheres of economy;

- development of non-standard forms of employment with enhancing their advantages;

- promotion of digitalization of human resource management (including more effective hiring process, e-learning, e-evaluation, digital applications for leadership and virtual collaboration for better decision making);

- consideration of the workforce virtual mobility as one of the solutions to the problem of spatial mobility.

The policy should also meet the growing challenges in the national social protection system and specify requirements for its further development taking into account the impact of emerging transformations in the labour market of Ukraine. Hence, in terms of the on-going transformations, trade unions are considered to play important roles in the regulation of non-standard forms of employment. The unions should reconsider the basic principles of mutual help and solidarity, as well as change the nature of their activities.

\section{Conclusion}

Development of new trends and forms of employment has significantly transformed social and labour relationships in Ukraine. We now observe a changing attitude of employers towards employees' loyalty and labour mobility. The change of employers' value orientations deals with the practices of staff reduction, staff leasing and outsourcing (especially popular among fast growing Ukrainian ICT companies), the fixed-term contract arrangements and so on. In the scope of virtual or another nonstandard employment, the so-called 'new labour contracts' set new 'employer-employee' relationships by fixation and confirmation of nonstandard employment conditions in employment contracts (formal relations) or by an actual rejection of the standard conditions, regardless of an employment contract (informal relations). The key characteristics of a new type of labour relations are the lack of secure, long-term employment, the limited or no guarantees for career mobility and related benefits (sequence of positions, skills upgrading, professional status improvement, etc.). The things that employees are usually promised concern an interest- 
ing work nevertheless requiring considerable efforts, flexible working mode, professional growth and competitiveness in the labour market (necessary in search of new jobs), and other perspectives. At the same time, the employers' benefits lie in the flexibility of employment relationships, in the ability of changing and mitigating sudden fluctuations in economic conditions, in the possibility of creating jobs for disabled people and in opportunities to reduce personnel costs. As a result, there is a distinct process of replacement of a closed employment policy of the companies, protecting their own staff from the labour market impact, by an open policy based on temporary, external workers, who themselves take full responsibility for their own career. Such a situation leads to precarization of labour in Ukraine, which can be seen in shift from secure, permanent employment to less paid and more insecure jobs.

In general, global and Ukrainian labour markets can be defined by the ICT-caused transformations and progress, by changing labour concepts, practises and relationships. Therefore, many countries, including Ukraine, face the problem of inadequate employment policies, which fail to address the challenges, new rules and requirements of the fast developing labour markets. Policymakers usually underrate the fact that new forms of employment cover a significant innovative potential as well as a shadow side (informal arrangements), which exacerbates the problem of replenishment of funds for social priorities and the shortfall of the state budget tax revenues.

Thus, the main priorities and principles of an efficient employment policy of Ukraine should be based on proactivity, flexicurity, advanced practices and innovative solutions adoption in order to build mutually beneficial and socially responsible 'employer-employee' relationships.

\section{Bibliography}

AUER, P., 2010. What's in a Name? The Rise (and Fall?) of Flexicurity. Journal of Industrial Relations, 52 (3), pp. 371-386.

BIL, M. M., 2016. Institutional Preconditions of European Development Vector of Ukraine's Labor Market. Regional Economy, 3, pp. 128- 


\section{4.}

1. DOU, 2016 (December, 28). [online]. Ukrainian IT Market: The Outcome for 2016 and Prospects for 2017 [viewed 19 September 2018]. Available from: https://dou.ua/lenta/articles/ 2016-summary.

EUROFOUND, 2017 (November, 24). [online]. Atypical work. European Observatory of Working Life. [viewed 20 October 2018]. Available from: https://www.eurofound.europa.eu/ observatories/eurwork/industrial-relations-dictionary/atypical-work.

ILOSTAT, 2018. [online]. Key Indicators of the Labour Market. Informal Employment [viewed 17 August 2018]. Available from: http://www.ilo.org/ilostat-files/Documents/Excel/MBI_524_EN.xlsx.

INTERNATIONAL LABOUR ORGANIZATION, 2018. [online]. Non-Standard Forms of Employment [viewed 12 September 2018]. Available from: http://www.ilo.org/global/topics/ non-standardemployment/lang--en/index.htm.

IVANOVA, L. V., NYKYFORENKO, V. H., 2013. The Use of NonStandard Forms of Employment in Today's Job Market, Journal of Social and Economic Research, 2 (49), pp. 109-115.

SCHMID, G., 1995. Is Full Employment Still Possible? Transitional Labour Markets as a New Strategy of Labour Market Policy. Economic and Industrial Democracy, SAGE, 16, pp. 429-456.

SCHMID, G., 2006. [online] Social Risk. Management through Transitional Labour Markets. Socio-Economic Review, 4, pp. 1-33 [viewed 19 September 2018]. Available from: https://doi.org/10.1093/SER/mwj029.

SHYLNIKOVA, Z. M., 2013. Impact of Information and Communication Technologies on the Labour Market and Employment. Bulletin of the Volodymyr Dahl East Ukrainian National University, 7 (196), Vol. 2, pp. 192-199.

STARTUPDEPOT, 2017. [online]. How Freelance has changed in Ukraine for 5 Years: Competition, Specialty, Rating [viewed 29 September 2018]. Available from: http://startupdepot.lviv.ua/yak-zminyvsyafrilans-v-ukrayini-za-5-rokiv.

STATE STATISTICS SERVICE OF UKRAINE, 2017 (a). Economic Activity of the Population of Ukraine 2016: Statistical Yearbook / State Statistics Service of Ukraine. - Kyiv, 2017. - 205 p. 
STATE STATISTICS SERVICE OF UKRAINE, 2017 (b). Labour Market in Ukraine, 2017: Statistical Yearbook / State Statistics Service of Ukraine. - Kyiv, 2017. - 30 p.

TSIZHMA, Yu. I., 2013. The Concept of Flexicurity and NonStandard Forms of Employment. BusinessInform, 7, pp. 197-202. 